\title{
Congenital Abnormality of the Large Intestine
}

National Cancer Institute

\section{Source}

National Cancer Institute. Congenital Abnormality of the Large Intestine. NCI Thesaurus.

Code C98881.

A malformation in any part of the large intestine that is present at birth. 